\title{
Integrated Thematic Context on Contextual Learning Based on English Learning Process in the Fifth Year at As Shofa Islamic Elementary School
}

\author{
Marhamah, Witri Handayani, Mukhaiyar, Syahrul Ramadhan \\ Education Department of Universitas Islam Riau \\ marhamahahmadhamid@gmail.com,
}

\begin{abstract}
This article is aimed to describe integrated thematic context on contextual learning based on English learning process in the Fifth Year of As Shofa Islamic Elementary School. The increasing in the learning quality and the learning result of the students can be interpreted and manipulated by applying the contextual learning appropriately on integrated thematic context in primary school. This integrated thematic context is applied on some English learning skills, such as listening, speaking, reading and writing on contextual learning based. The process of application consists of planning, implementing and assessing/reflextion with some considerations in applying each step of the process, such as characteristics of the students, interest of the students, needs of the students and many more. The utilization of contextual learning is purposed to include the real situation in daily life into the learning process. Interview result from the teachers is used to complete the description of discussion on this study. The result of the study shows that integrated thematic context on contextual approach on language learning process in As Shofa elementary school has supported the language skills of the students in many contexts.
\end{abstract}

Keywords-integrated thematic context; contextual learning based; primary school

\section{INTRODUCTION}

The condusive learning context can be created and applied by utilizing the appropriate learning approach. To gain the learning context, some components of learning should be concerned such as the objective, material, teachers, students, activities, and supporting facilities. Since 2013 curriculum come into account, the integrated thematic learning has been used in the learning process, especially in primary school - elementary school. The objective of the learning is to combine some subjects in one learning theme. The students not only learn one subject separately but also learn all subjects integratedly in one theme or learning activity (Depdiknas, 2006).

There are some characteristics of this integrated thematic learning, such as 1) Students center, 2) Give direct experience to the students, 3) Unclear subject saparation, 4) Provide concept from some subjects, 5) Flexible, 6) Learning process can be developt depends on the students' interests and needs through process evaluation and students' learning result ((Depdiknas, 2006); (Trianto, 2013);(Trianto, 2012); (Yanti, 2016)). To set the characteristics in context, high integrity teachers are requirely needed in the effort to obtain education objectives. The teachers can develop their own potention and give motivation to the students by an appropriate learning approach (Slavin, 2005); (Gredler, 2009). One of the approach that is used on the integrated thematic learning concept on language learning is contextual learning approach ((Johnson, 2002); (Glynn \& Winter, 2004); (Berns \& Erickson, 2001)).

Contextual learning approach is the learning which relates the learning material to the students' real life. This approach utilization is matched and considered with the material that is being tought, situation, class condition, tools, infrastructure and else. It means that contextual learning is an activity which can help and motivate the students to link the material and knowledge that is tought with the real situation in family and society ((Glynn \& Winter, 2004); (Wina, 2006); (Hakim, 2014)). The real life material that is used in this occasion is the language learning material with integrated thematic learning context. Therefore, this article describes the concept of an integrated thematic learning context which adopt contextual learning based in language learning ((Gredler, 2009); (Hamalik, 1993); (Mujimin, 2006); (Nurhadi, 2004)).

The language learning process is described by using content analysis technique with descriptive qualitative approach. The object of the research is observed comprehensively with the purpose to clearly describe the integrated thematic context on contextual approach based in language learning process ((DePorter Bobbi, Mark Reardon, 2001); (Purnomo, M. E. D. 2004); (Smith Patricia L and Tilman, 1999)).

In this paper, the writers wanted to describe the integrated thematic context on contextual learning based on English learning process in the fifth year of As Shofa islamic elementary school. Those descriptions can be seen on the answers of several questions of interview that have been responded by English teachers of SD Islam As-Shofa Pekanbaru. 


\section{DISCUSSION}

The integrated thematic context approaches with contextual approach based in language learning is described based on some learning steps. The steps (Trianto, 2013) are devided into three steps, that are preparing, implementing, and assessing. The first step is preparing which consists of basic competence mapping, development of theme network, development of syllabus, and the composing of learning application planning. The basic competence mapping consists of some activities: first, explanation activity of general objective (Standard Competence or Core Competence) and specific learning (Basic Competence) to the indicator. Second, the activity of theme determination by conducting some principles: 1) Pay attention to the environment which close to the students, 2) From the easiest into the most difficult one, 3) From the simplest into the most complex, 4) From the concrete into abstract, 5) The selected theme must provoke the thinking process of the students, 6) The scope of the theme is selected based on the age and students development, including their interest, needs, and ability. The third activities are theme network development, syllabus development and Lesson Plan organization.

The second step - implementing - consists of three phases: opening or introduction/ exploration, main activity/elaboration, and closing/confirmation. The opening or introduction /exploration is needed to create the initial atmosphere of learning to encourage the students to be more focus and well engaging in learning activity. The characteristic of this opening activity is a warming up. At this stage, more exploration about students experience of the theme is conducted, for example by telling a story, singing, or physical activity. For elaboration/main activity, the focus is on the activity which develop the reading, writing and calculating skills. The learning material is given by using some variative methods or strategies, and can be done clasically by group or individual. Last is closing/confirmation. The function of this activity is as calming activity or to end the learning activity. The closing can be done by concluding or stating the learning result.

Meanwhile, the assessing step is an activity to gain information periodically, continuously and comprehensively about the process and result from the growth and development which have been achieved by the students through the learning process. This activity needs an accurate assessment tools, like writing and oral test, portfolio and daily note of the students development.

\section{Planning}

The description of the learning approach steps above is as followed:

The integrated thematic learning context is the combination of some subjects to become one theme. The subjects are mathematics, science, and Indonesian. The theme can be seen on the list of theme which describes the main competence and basic competence of 2013 curriculum. The learning process is set based on some themes and sub themes. The teachers are free to choose the theme. For example for Grade 1 of primary school semester 1 , theme 1 is about Myself which consists of some sub theme, such as Me and My Friend, My Body, I take care of my body, and I am special. Theme 2 is about My Hobby which consists of the sub theme: Hoby of sport, Singing and dancing, Drawing and Reading. Theme 3 is about My activity which consists of the sub theme: Morning activity, Early afternoon activity, Afternoon activity, and Evening activity. Theme 4 is about My family which consists of the sub theme: My family members, My family activity, My extended family, and Togetherness in the family. The other themes can be seen on 2013 curriculum. This learning process is conducted for 6 x 35 minutes for Primary School, 6 x 40 for Secondary School and $6 \times 45$ for Tertiary School. Meanwhile, based on interview to teachers in As Shofa Islamic elementary school, for grade 5, the planning theme for semester 1 as follow, theme 1 is about introducing one self. Theme 2 is about My Family. Theme 3 is about My Favorite Teacher and theme 4 is about My friend. Furthermore, for semester 2, theme 1 is about my house, theme 2 is about my classroom, theme 3 is about my neighbor, and theme 4 is about my country. The important thing for consideration is the theme should be correlated to the theme in thematic-integrated subject curriculum 2013, mathematics, science and Indonesian. Thus, the allocation time in English teaching and learning process for elementary school is about 35 minutes also. It means that it runs $2 \times 35$ minutes a week. Besides, the teacher planed not only the lesson plan for several meetings in every semester but also the others things that teacher need for teaching and learning activities that have been planned before entering the class.

\section{Implementing}

The learning implementing starts with the greetings from the teachers to the students, arranging the students sit, and guiding the prayer, then the teachers do the apperception by asking questions about the things that related to the theme. Then, the teachers utters the theme, sub theme, and the learning which about to be done, objective and outline of the learning activity. Especially in As Shofa Islamic elementary school, the teachers give motivation and advices in Islam to the students. It should be related to the theme. That advices can be found in Al-qur'an and Hadist. Surely, not only this activity should be written in lesson plan or module for English but also the sentence from Al-qur'an and Hadist. For example, for the theme about time, the teachers choose surah al ashr (time) that consists of three sentences that describes about the benefit of time in the world. It suggests them that English is an universal language ((DePorter Bobbi, Mark Reardon, 2001); (DePorter \& Hernacki, 2000); (Syah, 2010)). 
Next is constructivity activity, this activity is started by telling the story of new friend (theme) or singing the song that related to the theme, playing the video about the related theme, or telling two students to introduce themselves each other by having dialogue or with another related topics. Then, the teachers ask the students whether they have new friend. Moreover, the students are asked to tell the things which relate to introducing self (name, address, hobby, the number of siblings, and anything else which relate to the theme). The teachers guide the students to tell the story about new friend ( the theme related). This activities could describe which students who were active in class during the learning process. They speak spontaneously and smoothly ((Sukmadinata, 2004); (Sardiman, 2000)). For example, in dialogues in introducing oneself, they came in front of the class. They did the conversation until the end face to face. They were able to construct their knowledge and apply it in the dialogues.

Next activity is the inquiry. The students read the text about new friend (related theme) which contain in the students' book. Then, the students is guided by the teachers to find the important things (somebody's identity) from the text. After the students find the important things from the text, the teachers ask the students to formulate the appropriate title that matches the reading text (Lie, 2002). Then, the students make a mind mapping from the reading text. In this activity, the students created a beautiful picture by writing the idea by themselves. They can find the difficult words by looking up the dictionary. Besides, the students of SD Islam As Shofa were creative and smart, it is easy for them to create the mind mapping. Some of English words have already been mastered by them. The note that the teacher should listed is the English word. That is why the students know the words easily. They are not only mastering the words but also knowing the words because they practiced them every time and everywhere.

Then at the questioning activity, the teachers and students ask about new friend (related theme). The students write the questions on the white board and the teachers ask another students to respond the questions that are in the white board. Last, the teachers guide the students to conclude the answer. In this activity, it can be seen that they were active asking and giving questions to each other.

The activity continue to the learning society activity in which the students are divided into groups which consists of 5 members (depend on the number of the students in the classroom). Then the teachers devide the students' workbook to each group. In this group activity, the students note the identity they find in the text about Me and My Friend (related theme). The students then combine the data that they have with the other group's data. The result of the data combination is written on the table by using stake (numerical classifier for long narrow objects).

Furthermore, on modeling activity, the teachers show two people from different region to the students. The teachers motivate the students to ask questions to the people. The students listen to teachers' explanation about the identity of the people. Then, the teachers ask the students to mention the things they should aware related to introduction to new friend (related theme). For reflection activity, the teachers ask about the material which has been discussed. They ask the students if there were any materials that they did not understand yet. Then, the teachers guide the students to conclude the learning material. Last, the teachers help the students to correct the inappropriate things on the conclusion.

Next, on assessing activity, actually, the teachers do assessing process during the learning activity. The teachers do the assessing through students' workbook and the basic leadership exercise which is done by the students. They give the questions and tasks which relate to the students daily life. The teachers, then, ask the students to sit on their former position. Next, the students together with the teachers conclude the lesson. After that, the teachers strengten the given material to the students and give message to always be polite in introducing yourself to new friend. Last, the lesson is closed with Hamdalah.

\section{Assessing/ Reflection}

The assessing is given in this stage to find the result and to know whether the planning and the implementing process are synhronized. Whether there is any progress in the learning result of the students. Beside, the teachers also note down any other important details.

It is clear that the six steps or stages of contextual approach above cannot be saparated from the integrated thematic context in language learning which has four language skills. In addition there are themes and sub themes which are integrated to some subjects by using some language skills like listening, speaking, reading and writing.

\section{CONCLUSION}

Integrated thematic context on contextual approach on language learning process in As Shofa elementary school has support the language skills of the students in many contexts. The themes and sub themes have been put as the stepping stone to be integrated with language skills, such as listening, speaking, reading and writing. Because 2013 curriculum integrate all language skills into reading skill. The mathematics, science and Indonesian subjects should be integrated in those themes and made the students understand the text by using some other language skills. All in all, they have knowledge of one things in the others. The application of this research can lead the students to use their maximum capability to master some subjects and English language in the same time. 


\section{References}

Berns, R. G., \& Erickson, P. M. (2001). Contextual Teaching and Learning: Preparing Students for the New Economy. The Highlight Zone: Research at Work No. 5.

Depdiknas. (2006). Permendiknas no 22 tahun 2006. Jakarta: Depdiknas.

DePorter, B., \& Hernacki, M. (2000). Membiasakan Belajar Nyaman dan Menyenangkan. Bandung: Kaifa.

DePorter Bobbi, Mark Reardon, S. S.-N. (2001). Quantum teaching: Memperaktikkan quantum learning di ruangruang kelas. Bandung: Kaifa.

Glynn, S. M., \& Winter, L. K. (2004). Contextual teaching and learning of science in elementary schools. Journal of Elementary Science Education, 51-63.

Gredler, M. (2009). Learning and instruction: Theory into Practice. Upper Saddle River, N J: Merrill.

Hakim, I. N. (2014). Pembelajaran Tematik Integratif di SD/MI dalam Kurikulum 2013. Insania, 19.

Hamalik, O. (1993). Strategi belajar mengajar. Bandung: Mandar Maju.

Johnson, E. B. (2002). Contextual teaching and learning: What it is and why it's here to stay. Corwin Press.

Lie, A. (2002). Cooperative learning: Memperaktikkan cooperative learning di ruang-ruang kelas. Jakarta: Gramedia Widiasarana Indonesia.

Mujimin, W. (2006). Implementasi Pembelajaran Tematik bagi Anak Berkelainan. Jurnal Pendidikan Khusus, 2.

Nurhadi, B. Y. A. G. S. (204AD). Pembelajaran Kontekstual dan penerapannya dalam KBK. Malang: Universitas Negeri Malang.

Sardiman. (2000). Interaksi dan motivasi belajar mengajar. Jakarta: PT Raja Grafindo Persada.

Slavin, R. . (2005). Cooperative learning: Theory, research and practice. London: Allymand Bacon.

Smith, P.L \& Tilman. (1999). Instructional design. New York: John Wiley \& Sons.

Sukmadinata, N. S. (2004). Kurikulum dan pembelajaran kompetensi. Bandung: Kesuma Karya.

Syah, M. (2010). Psikologi belajar. Jakarta: Rajawali Press.

Trianto. (2012). Model pembelajaran terpadu. Konsep, strategi dan implementasinya dalam ktsp. Jakarta: Bumi Aksara. Jakarta: Bumi Aksara.

Trianto. (2013). Desain pengembangan pembelajaran tematik bagi anak usia dini tk/ra \& anak usia kelas awal sd/mi. jakarta: PT Fajar Interpratama Mandiri.

Wina, S. (206AD). Strategi pembelajaran : Berorientasi standar proses pendidikan. Jakarta: Kencana Predana.

Yanti, N. (2016). Peningkatan Proses Pembelajaran Tematik Terpadu Menggunakan Contextual Teaching and Learning (CTL) Di Kelas IV Sekolah Dasar. Inovasi Pembelajaran Sd, 1 . 